\title{
The relationships among lumbar region width, back muscling and musculus longissimus lumborum et thoracis area in Blonde d'Aquitaine bulls and heifers during rearing period
}

\author{
LUDĚK STÁDNÍK, ALENA JEŽKOVÁ, FRANTIŠEK LOUDA, JANA DVOŘÁKOVÁ and \\ LADISLAV ŠTOLC
}

Department of Animal Husbandry, Faculty of Agrobiology, Food and Natural Resources, Czech University of Life Sciences, Prague, Czech Republic

\section{Abstract}

The objective of this study was to determine the predictive value of lumbar region width, measured with a tape (WT) and Wilkinson's trammel (WW), and the ultrasounded musculus longissimus lumborum et thoracis (MLLT) area in the 1st lumbar vertebra, and back muscling (BM) in bulls and heifers of the Blonde d'Aquitaine (BA) breed during the rearing period for selection of breeding animals, concentrating on the MLLT area and muscling. Two generations of bulls $(n=63)$ and heifers $(n=68)$ of BA breed $(n=61)$ and crossbreds Czech Pied Cattle $\times$ Blonde d'Aquitaine $(C \times B A)(n=70)$ born between December 2004 and June 2006 were included in the investigation. Measurements of the WT, the WW, the MLLT area and subjective judging of the BM were performed at 120, 210 and 365 days of age. The effects of lumbar region width in the 1st lumbar vertebra level, the level of back muscling and that of the MLLT area were used to determinate the relationships among dependent variables at the given ages of the animals. Better muscling of the back or a larger MLLT area during the entire period of rearing was determined in relation to a wider lumbar region $(P<0.05-0.001)$, whereas more significant results were detected during measurement of the WT. Direct dependencies were confirmed by evaluation of the MLLT area at 210 and 365 days in relation to the BM at the same age $(P<0.05-0.01)$. The trend of dependence between the MLLT at 210 and 365 days of age was stated, a larger MLLT at 210 days of age predicted a larger MLLT at 365 days of age, from $2.58 \mathrm{~cm}^{2}$ to $6.21 \mathrm{~cm}^{2}$. The values of the WT and the WW at 120,210, and 365 days and level of the BM at 210 and 365 days of age can be also considered objective and acceptable characteristics for the selection of animals aimed at the MLLT area at the same age.

Keywords: beef cattle, Blonde d'Aquitaine, lumbar width, beefiness, ultrasound 


\section{Zusammenfassung}

\section{Beziehungen zwischen der Lendenbreite, der Rückenbemuskelung und der Fläche des $\boldsymbol{M}$. longissimus lumborum et thoracis von Bullen und Färsen der Rasse Blonde d'Aquitane während der Aufzuchtperiode}

Untersucht wurden die Beziehungen zwischen der mit dem Maßband (WT) und dem Wilkinsonzirkel (WW) am 1. Lendenwirbel gemessenen Lendenbreite, der subjektiv geschätzten Rückenbemuskelung (BW) und der durch Ultraschallmessung erfassten Fläche des M. lumborum et thoracis (MLLT). Einbezogen waren aus zwei Geburtsjahrgängen zwischen Dezember 2004 und Juni 2006 geborene 63 Bullen davon 27 Blonde d'Aquitaine (BA), 68 Färsen davon 34 BA sowie 70 Kreuzungstiere (Czech Pied Cattle $\times$ Blonde d'Aquitaine, $[C \times B A])$ deren Werte jeweils am 120., 210. und 365. Tag erfasst wurden. Es ergaben sich in Abhängigkeit von der Lendenbreite insbesondere am 365 Tag signifikante Beziehungen zur Lendenbemuskelung. Die WT und WW Werte am 120 Tag können als geeignete Merkmale für die MLLT Werte sowohl am 210. als auch am 365. Tag und damit als Auswahlkriterien betrachtet werden.

Schlüsselwörter: Fleischrind, Blonde d'Aquitaine, Lendenbreite, Fleischigkeit, Ultraschall

\section{Introduction}

In recent years attention of breeders has been focused on the possibilities of evaluation (PŘIBYL et al. 2008a) or prediction of beef production during the rearing period (MARLEKÖSTER et al. 2000, CHOAT et al. 2006). Many authors have studied the effect of quantity and quality of feeding ration on growth, carcass traits, and meat quality (BARTOŇ et al. 2007, HOLLÓ et al. 2008). Presently, several basic methods are used for observation and evaluation of growth and beef production (ENGELHARDT et al. 1992). PǨIBYL et al. (2007), KREJČOVÁ et al. (2007a, 2007b, 2008), and PŘIBYL et al. (2008b) evaluated the trajectory of body weight and daily gain using different models during a performance test in dualpurpose bulls. VOSTRÝ et al. (2008) estimated the genetic parameters for the population and the heterosis effect on growth traits in crossbred cattle in the Czech Republic. Weighing is most frequently used for evaluation of growth. On the other hand, measurement of body proportions is used only extraordinarily (STEINHAUSER et al. 2000). Ultrasound evaluation of the musculus longissimus lumborum et thoracis (MLLT) area is more frequently used for detailed monitoring of beef production during the rearing or fattening period (MAY et al. 2000). BRETHOUR (2000) was concerned with repeated measurement of the MLLT in relation to subcutaneous fat or beef marbling during the rearing, while HASSEN et al. (1999) focused on relationships between the MLLT, the layer of subcutaneous fat, and quantitative, and qualitative traits of carcass body. The training and knowledge of technicians are fundamental for obtaining a correct ultrasound image and its accurate interpretation (PFEIFFER et al. 1985, HERRING et al. 1994). RÖSLER et al. (1996) and HASSEN et al. (1998) evaluated the effect of the technician on the quality of data obtained by ultrasound and the possibilities of their subsequent usage. However, POLÁK and DAŇO (2002) assumed the possibility of usage the ultrasound as a helpful or even the most suitable method for classification of bull carcasses. Muscling has a close 
relationship to quality traits of the carcass body. It is possible to derive prediction equations, based on the muscling of live animals, which can specify presumptions for quality of the carcass body after slaughtering or for selection (FIELD 2000, BERGEN et al. 2005). Evaluation of muscling in connection with ultrasound in live animals can be utilized for the improvement of breeding programs (DRENNAN and MCGEE 2006).

The objective of this study was to determine the predictive value of lumbar region width and the MLLT area in the 1st lumbar vertebra, and back muscling in bulls and heifers of Blonde d'Aquitaine breed during the rearing period for selection of breeding animals, concentrating on the MLLT area and muscling.

\section{Material and methods}

Two generations of bulls ( $n=63,27$ purebreed Blonde d'Aquitaine [BA] bulls and 36 crossbreeds Czech Pied Cattle $\times$ Blonde d'Aquitaine [CXBA]), and heifers $(n=68,34$ purebreed BA heifers and 34 crossbreeds $(\times B A)$ born between December 2004 and June 2006 were included in the experiment. A total of 61 animals of BA and 70 crossbreds CXBA were evaluated.

The bulls and heifers were housed in four newly reconstructed cowbarns in groups of about 20 in relation to their sex and age from November to April. Paddocks with settled surface were available to all the animals during housing in the winter period. Deep-litter removed once per month was used for housing in the cowbarns. The feeding ration was accessible ad libitum in the feeding manger. The animals were fed a total mixed ration based on roughage during the winter season. All the animals were kept in a pasture during the grazing period from May to October. Mineral licks were available during the entire year. The calves stayed in the herd with their mothers until the end of the grazing season. Reproduction management in the herd included seasonal mating and subsequent calving from December to June. A total of 7 sires ( $n$ of offsprings was from 2 to 38 ) were used for mating 65 dams during the two mating and subsequently rearing seasons observed.

Measurement of lumbar region width in the 1st lumbar vertebra (LV) was performed with a tape (WT) and Wilkinson's trammel (WW) (accuracy $0.5 \mathrm{~cm}$ ), and subjective evaluation of back muscling (BM) by a technician of the Czech Beef Breeders Association in accordance with the Methodology of describing and judging of beef cattle breeds exterior. The level of muscling was judged according to 10-point scale, 10 points being the maximum and 1 point the minimum classification. All the measurements were performed at 120, 210 and 365 days of age. Ultrasound measurement of the MLLT in the 1st lumbar vertebra (MLLT) using the ultrasound machine ALOKA SSD-500 (ALOKA Co. Ltd., Tokyo, Japan) equipped with a 3.5-MHz $17.2 \mathrm{~cm}$ linear array probe UST5512U-3.5 was carried out. The transducer was positioned laterally to the 1st LV on the left side of the animal. Ultrasound examination of MLLT was recorded with a DVD recorder Panasonic DMR-EH55 to digital quality of the images for analysis by Lucia 4.1 software (Laboratory Imaging s.r.o.) as follows. The quality of the images obtained was affected by the application of a sufficient quantity of vegetable oil and ultrasound gel on the animals' coats before investigation of the MLLT. The merging of 2 images was necessary for the measurement of the MLLT at 210 and 365 days of age. The dataset was analysed by 
ANOVA (RASCH and MAŠATA 2006) through the statistical program SAS STAT 8.0-GLM (SAS Institute, 2001). The effects of the level WT, WW and MLLT in the 1st LV, and the level of BM were used in addition to the basic factors included in the linear model used (sex, birth season, breed, sire) to determine the relationships among dependent variables at the given ages of the animals. In accordance with the results of the dataset, the animals were divided into 3 groups, detailed division is described in linear model. Evaluation was performed using the following general linear model:

$$
Y_{i j k l m n o}=\mu+A_{i}+B_{j}+C_{k}+D_{l}+F_{m}+b_{n} V+e_{i j k l m n o}
$$

where $Y_{i j k l m n o}$ is the observed value of the WT, the WW and the MLLT in the 1st LV and the BM at 120,210 and 365 days of age, $\mu$ the average value of dependent variable, $A_{i}$ the fixed effect of $i$-class of sex $\left(i=q, n=68 ; \hat{\gamma} n=63\right.$ ), $B_{j}$ the fixed effect of $j$-class of birth season ( $j=$ December-March, $n=44$; April-June, $n=87$ ), $C_{k}$ the fixed effect of $k$-class of breed ( $k=\mathrm{BA}, n=61 ; \mathrm{C} \times \mathrm{BA}, n=70), D$, the fixed effect of $l$-class of sire ( $=\mathrm{ZBA} 180, n=7 ; \mathrm{ZBA}$ 264, $n=38 ;$ ZBA 282, $n=2 ;$ ZBA 298, $n=31$; ZBA 361, $n=29 ;$ ZBA 388, $n=19 ;$ a ZBA 998, $n=5$; ZBA [Blonde d'Aquitaine bulls used in natural mating]), $F_{m}$ the fixed effect of $m$-class of the level WT, WW and MLLT in the 1st LV or the level of BM at 120, 210 and 365 days of age $\left(n=1\right.$ : to $\bar{x}-1 / 2 S_{d}, 2$ : from $\bar{x}-1 / 2 S_{d}$ to $\bar{x}+1 / 2 S_{d}, 3$ : over $\left.\bar{x}+1 / 2 S_{d}\right), b_{n} V$ the regression to the animal's age at the time of measurement, $e_{i j k l m n o}$ the residual effects (random error).

The differences between estimated variables were tested at the levels of significance $P<0.05, P<0.01$ and $P<0.001$.

\section{Results and discussion}

Selected parameters of growth and beef production at 120, 210 and 365 days of age were evaluated during observation in the 131 monitored animals. Lumbar region width in the 1st lumbar vertebra (LV) measured with a tape (WT) ranged from $27 \mathrm{~cm}$ to $49 \mathrm{~cm}$, with an average value of $34.9 \mathrm{~cm}$ at 120 days of age, from $30 \mathrm{~cm}$ to $54 \mathrm{~cm}$ with an average width of $42.2 \mathrm{~cm}$ at 210 days of age, and from $36 \mathrm{~cm}$ to $57 \mathrm{~cm}$ with an average value of $45.9 \mathrm{~cm}$ at 365 days of age. The average of lumbar region width in the $1 \mathrm{st}$ LV measured using Wilkinson's trammel (WW) reached $21.7 \mathrm{~cm}$ with a range from $17 \mathrm{~cm}$ to $28 \mathrm{~cm}$ at 120 days of age; $26.1 \mathrm{~cm}$ with a minimum value of $19 \mathrm{~cm}$ and a maximum value of $34 \mathrm{~cm}$ at 210 days of age; and the WW increased to an average of $29.5 \mathrm{~cm}$ with an interval from $25 \mathrm{~cm}$ to $40 \mathrm{~cm}$ at 365 days of age. The average of back muscling (BM) was 5.8 points and varied from 2 to 9 points at 120 days of age. The average value of BM increased to 6.5 points with a range from 4 to 9 points at 210 days of age, and a technician evaluated the BM of animals from 4 to 8 points with an average of 6.3 points at 365 days of age. The musculus longissimus lumborum et thoracis (MLLT) area represented $44.3 \mathrm{~cm}^{2}$ on the average with a variation from $24.6 \mathrm{~cm}^{2}$ to $66 \mathrm{~cm}^{2}$ at 120 days of age. The MLLT increased to $55.3 \mathrm{~cm}^{2}$ with a range of $32.7 \mathrm{~cm}^{2}$ to $82 \mathrm{~cm}^{2}$ at 210 days of age, and the average MLLT reached $66.1 \mathrm{~cm}^{2}$ with a range of $42.5 \mathrm{~cm}^{2}$ to $89.5 \mathrm{~cm}^{2}$ at the end of the observation at 365 days of age. VOŘÍŠKOVÁ et al. (2002) confirmed a positive relationship between the MLLT, the age, and the slaughter weight of fattened animals.

The coefficient of repeatability for the evaluated linear model ranged from $r^{2}=0.1894$ to $r^{2}=0.6079$ during evaluation of the observed traits, its the lowest values being determined 
in relationship to the MLLT evaluation and the highest values in relationship to the WT and the WW in the 1st LV. The statistical significances of the entire models used for evaluation at 120 and 210 days of age were for the most part $P<0.0001$. Only when the $B M$ and the MLLT at 365 days of age were evaluated were the levels of statistical significance $P<0.001$ or $P<0.01$. The significance of the effect of the sire varied from $P<0.05$ to $P<0.0001$. A non-significant effect of the sire was found only during evaluation of the BM and the MLLT at 365 days of age. The effect of breed was confirmed as statistically significant only in the evaluation of all the dependent variables at 210 days of age and in the evaluation of WT, WW and BM at 365 days of age $(P<0.05-0.0001)$. BENE $e t$ al. (2007) found similar differences among cattle breeds in some body proportions in favour of Blonde d'Aquitaine. The present results documented the significant effect of a different genetic proportion of Blonde d'Aquitaine breed. BARTOŇ et al. (2006) found signifiant differences in quantitative as well as qualitative traits of beef production among beef breeds. Relationships between sex and WT or WW at 210 days of age, BM at 365 days of age, and the MLLT during the entire observation were not statistically significant, whereas relationships to other characteristics were significant. A statistically significant effect of birth season to BM at 120,210, and 365 days of age and to the MLLT at 210 days was found to be only $(P<0.0001)$. SZABÓ et al. (2006) also described in their findings the significant effect of sex and birth season on the growth of 8 beef breeds.

Table 1 documents the statistically significant direct relationship only between larger width of WT and higher value of the MLLT at 120 days of age, the differences representing $4.45-9.23 \mathrm{~cm}^{2}$. However, this trend was confirmed with relationship to all the evaluated characteristics at 210 and 365 days of age. Animals with a wider WT at 210 days of age had a wider WT or WW at 365 days of age, by $0.39-2.52 \mathrm{~cm}$. Significant differences were determined in the BM at 210 days of age in favour of those animals with the widest WT at the same age. The same trend was found at 365 days of age, when the differences were from 0.24 to 0.41 points, but without statistical significance. Differences from 6.82 to $12.81 \mathrm{~cm}^{2}$ in the MLLT at 210 days of age were measured as well. Table 1 also confirms the tendencies found at both 210 days and 365 days of age. The differences at 365 days of age ranged from 3.7 to $4.99 \mathrm{~cm}$ in WT or WW, from 0.58 to 0.6 points in BM and from 8.76 to $10.88 \mathrm{~cm}^{2}$ in the MLLT area. These results demonstrate, that WT can be considered as a valuable and objective trait, simply and practically applicable for evaluation of BM and MLLT at a given age, whereas more significant results were found from 210 days of age. BULLOCK et al. (1991) evaluated body proportions and body condition of cows. They performed ultrasound measurements and summarized that these methods can be used for the evaluation of carcass body. NOVÁ et al. (2003) detected significant differences between beef breeds in the WT and the WW. Mapping of these traits in beef cattle is necessary before evaluation of these characteristics as carcass traits and after that breeders can discuss including them in the system of evaluation and selection of fattened or breeding animals. However, the present results (PFEIFFER et al. 1985) in contrast to RÖSLER et al. (1996) do not indicate the possibility of accurate prediction of BM or MLLT for higher age. On the contrary, MARLE-KÖSTER et al. (2000) determined cannon bone length at birth as an early indicator of mature size and weights at different ages. 
Table 1 a-c

Relationships between lumbar region width measured by tape at 120 (1a), 210 (1b) and 365 (1c) days of age and other monitored traits

Die Beziehungen zwischen der Lendenbreite bei 120 (1a), 210 (1b) und 365 (1c) Tagen und anderen erfassten Merkmalen

1a-WT 120

\begin{tabular}{|c|c|c|c|c|c|c|c|c|}
\hline \multirow{2}{*}{ Trait } & \multirow{2}{*}{ Age } & \multicolumn{2}{|c|}{$<32.6 \mathrm{~cm}, n=44$} & \multicolumn{2}{|c|}{$32.6-37.3 \mathrm{~cm}, n=56$} & \multicolumn{2}{|c|}{$>37.3 \mathrm{~cm}, n=31$} & \multirow{2}{*}{$P$} \\
\hline & & $\mu+\alpha$ & SE & $\mu+\alpha$ & SE & $\mu+\alpha$ & SE & \\
\hline \multirow{2}{*}{ WT } & 210 & 42.1 & 0.83 & 42.6 & 0.76 & 42.2 & 0.85 & - \\
\hline & 365 & 45.0 & 0.83 & 45.2 & 0.76 & 43.6 & 0.85 & - \\
\hline \multirow{2}{*}{ WW } & 210 & 25.7 & 0.49 & 26.5 & 0.45 & 26.4 & 0.50 & $1: 2^{*}$ \\
\hline & 365 & 28.6 & 0.55 & 29.1 & 0.50 & 27.2 & 0.56 & $1: 3^{*}, 2: 3^{* *}$ \\
\hline \multirow{3}{*}{ BM } & 120 & 5.5 & 0.26 & 5.7 & 0.23 & 5.5 & 0.26 & - \\
\hline & 210 & 6.7 & 0.19 & 6.8 & 0.17 & 6.8 & 0.20 & - \\
\hline & 365 & 6.4 & 0.19 & 6.5 & 0.17 & 6.4 & 0.20 & - \\
\hline \multirow{3}{*}{ MLLT } & 120 & 38.8 & 1.62 & 43.6 & 1.47 & 48.0 & 1.65 & $1: 2-3^{* * *}, 2: 3^{*}$ \\
\hline & 210 & 52.1 & 2.04 & 53.1 & 1.88 & 55.7 & 2.11 & - \\
\hline & 365 & 66.6 & 2.24 & 64.8 & 2.03 & 61.3 & 2.28 & - \\
\hline
\end{tabular}

$1 \mathrm{~b}-$ WT 210

\begin{tabular}{|c|c|c|c|c|c|c|c|c|}
\hline \multirow{2}{*}{ Trait } & \multirow{2}{*}{ Age } & \multicolumn{2}{|c|}{$<39.7 \mathrm{~cm}, n=46$} & \multicolumn{2}{|c|}{$39.7-44.7 \mathrm{~cm}, n=42$} & \multicolumn{2}{|c|}{$>44.7 \mathrm{~cm}, n=43$} & \multirow{2}{*}{$P$} \\
\hline & & $\mu+\alpha$ & SE & $\mu+\alpha$ & SE & $\mu+\alpha$ & SE & \\
\hline WT & 365 & 43.55 & 0.81 & 44.46 & 0.51 & 46.07 & 0.86 & $1: 3^{*}$ \\
\hline WW & 365 & 27.73 & 0.56 & 28.48 & 0.55 & 28.87 & 0.59 & - \\
\hline BM & $\begin{array}{l}210 \\
365\end{array}$ & $\begin{array}{l}6.50 \\
6.23\end{array}$ & $\begin{array}{l}0.19 \\
0.19\end{array}$ & $\begin{array}{l}6.69 \\
6.40\end{array}$ & $\begin{array}{l}0.19 \\
0.18\end{array}$ & $\begin{array}{l}7.06 \\
6.64\end{array}$ & $\begin{array}{l}0.20 \\
0.20\end{array}$ & $\begin{array}{l}1: 3^{*} \\
-\end{array}$ \\
\hline MLLT & $\begin{array}{r}210 \\
365 \\
\end{array}$ & $\begin{array}{l}48.11 \\
62.26 \\
\end{array}$ & $\begin{array}{l}1.86 \\
2.20 \\
\end{array}$ & $\begin{array}{l}54.10 \\
63.02 \\
\end{array}$ & $\begin{array}{l}1.86 \\
2.19 \\
\end{array}$ & $\begin{array}{l}60.92 \\
64.10 \\
\end{array}$ & $\begin{array}{l}1.99 \\
2.35 \\
\end{array}$ & $\begin{array}{l}1: 2^{* *}, 1: 3^{* * *}, 2: 3^{* *} \\
-\end{array}$ \\
\hline \multicolumn{9}{|c|}{ 1c-WT 365} \\
\hline Trait & Age & \multicolumn{2}{|c|}{$<43.8 \mathrm{~cm}, n=37$} & \multicolumn{2}{|c|}{$43.8-48.1 \mathrm{~cm}, n=57$} & \multicolumn{2}{|c|}{$>48.1 \mathrm{~cm}, n=37$} & $P$ \\
\hline$\overline{W W}$ & 365 & 26.95 & 0.39 & 28.24 & 0.33 & 31.94 & 0.46 & $1: 2-3^{* * *}, 2: 3^{* * *}$ \\
\hline BM & 365 & 6.35 & 0.18 & 6.37 & 0.15 & 6.95 & 0.21 & $1: 3^{* *}, 2: 3^{* * *}$ \\
\hline MLLT & 365 & 61.43 & 2.03 & 63.55 & 1.72 & 72.31 & 2.36 & $1: 3^{* * *}, 2: 3^{* * *}$ \\
\hline
\end{tabular}

$\mu+\alpha$ least square mean, SE standard error of least square mean $P$ statistical significances of differences between groups, ${ }^{*} P<0.05,{ }^{* *} P<0.01,{ }^{* * *} P<0.001$

Table 2 shows the results, that statistically significant differences were not confirmed only in the evaluation of BM and MLLT at a given age in relation to WW. The statistical significance of differences ranged from $P<0.05$ to $P<0.001$ in evaluation of other observed traits. A significant difference of WT at 210 days of age by $1.82-3.49 \mathrm{~cm}$ was detected in the group of animals with the widest WW at 120 days of age. However, this trend was not confirmed at 365 days of age. Significant differences in BM were found only at 365 days of age in relation to WW at 210 and 365 days of age. These differences represented from 0.09 to 0.61 points assigned for BM. The MLLT always relates to WW only at the same age. A wider WW corresponds to a larger MLLT area, the differences being represented by $2.15-5.94 \mathrm{~cm}^{2}$ at 120 days of age, $5.25-7.38 \mathrm{~cm}^{2}$ at 210 days of age and $7.15-10.76 \mathrm{~cm}^{2}$ at 365 days of the observed animal's age. A direct trend between the MLLT area and WW at the same age was similarly found as during evaluation by WT. The 
same trend confirms Pearson's correlation coefficients located between WT and WW. These ranged from $r=0.730$ at 120 days of age to $r=0.850$ at 365 days of age $(P<0.05)$ (DVOŘÁKOVÁ et al. 2007). VESELÁ et al. (2006) detected phenotypic correlations from $r=0.69$ to $r=0.87$ among traits of muscling and production type, but coefficients were lower in relation to body proportions. COOPMAN et al. (2007) confirmed that some body heights are related to live or slaughter weight, but they detected no relationships to muscling of the animals. Nevertheless in our study, higher levels of significance were detected in evaluation of BM and the MLLT area in relation to WT. In accordance with these results, we can conclude that WT is more suitable for evaluation of cattle muscling during the rearing period because it combines width proportion of the measured area and its concavity at the same time, and with this the beefiness and development of muscles as well. Similarly, ALONSO et al. (2007) studied the possibility of muscling and the quality of carcass body prediction based on selected body proportions of the back, lumbar region, and rump. POLÁK et al. (2007) used computer image analyses and computer photometry as a possible method for prediction of carcass quality in vivo. They summarized their findings as follows: Equations, which included photometric dimensions of the live animals' bodies and their live weight, achieved a value of $r^{2}$ from 0.83 to 0.92 . Their results indicate the possibility of carcass quality estimation without detailed dissection.

Table 2 a-c

Relationships between lumbar region width measured by Wilkinson's trammel at 120 (2a), 210 (2b) and 365 days (2c) of age and other monitored traits

Die Beziehungen zwischen der Lendenbreite am 120. (2a), 210. (2b) und 365. (3c) Tag und anderen erfassten Merkmalen

2a-WW 120

\begin{tabular}{lcccccccl}
\hline \multirow{2}{*}{ Trait } & \multirow{2}{*}{ Age } & \multicolumn{2}{c}{$\leq 20 \mathrm{~cm}, n=39$} & \multicolumn{2}{c}{$21-22 \mathrm{~cm}, n=56$} & \multicolumn{2}{c}{$\geq 23 \mathrm{~cm}, n=36$} & \multicolumn{2}{l}{$P$} \\
& & $\mu+\alpha$ & $\mathrm{SE}$ & $\mu+\alpha$ & $\mathrm{SE}$ & $\mu+\alpha$ & \multicolumn{1}{c}{$\mathrm{SE}$} & \\
\hline \multirow{2}{*}{ WT } & 210 & 40.66 & 0.79 & 42.33 & 0.67 & 44.15 & 0.83 & $1: 2^{*}, 1: 3^{* * *}, 2: 3^{*}$ \\
& 365 & 45.07 & 0.83 & 44.99 & 0.70 & 43.14 & 0.87 & $1: 3^{*}, 2: 3^{*}$ \\
\multirow{4}{*}{ WW } & 210 & 25.58 & 0.50 & 26.49 & 0.42 & 26.49 & 0.52 & - \\
& 365 & 28.52 & 0.56 & 28.57 & 0.48 & 27.36 & 0.59 & $2: 3^{*}$ \\
& 120 & 5.50 & 0.26 & 5.69 & 0.22 & 5.30 & 0.27 & - \\
BM & 210 & 6.58 & 0.19 & 6.82 & 0.16 & 6.75 & 0.20 & - \\
& 365 & 6.50 & 0.19 & 6.46 & 0.16 & 6.20 & 0.20 & - \\
& 120 & 40.67 & 1.71 & 44.46 & 1.45 & 46.61 & 1.80 & $1: 2^{*}, 1: 3^{* *}$ \\
MLLT & 1210 & 51.98 & 2.07 & 53.79 & 1.76 & 55.81 & 2.18 & - \\
& 365 & 64.33 & 2.28 & 64.73 & 1.93 & 64.98 & 2.39 & - \\
\hline
\end{tabular}

$2 b-W W 210$

\begin{tabular}{|c|c|c|c|c|c|c|c|c|}
\hline \multirow{2}{*}{ Trait } & \multirow{2}{*}{ Age } & \multicolumn{2}{|c|}{$<24.7 \mathrm{~cm}, n=32$} & \multicolumn{2}{|c|}{$24.7-27.4 \mathrm{~cm}, n=64$} & \multicolumn{2}{|c|}{$>27.4 \mathrm{~cm}, n=35$} & \multirow{2}{*}{$P$} \\
\hline & & $\mu+\alpha$ & SE & $\mu+\alpha$ & SE & $\mu+\alpha$ & SE & \\
\hline$\overline{\mathrm{WT}}$ & 365 & 42.76 & 0.94 & 44.52 & 0.68 & 45.92 & 0.83 & $1: 2^{*}, 1-2: 3^{* *}$ \\
\hline WW & 365 & 26.72 & 0.63 & 28.41 & 0.46 & 29.08 & 0.56 & $1: 2-3^{* *}$ \\
\hline \multirow[t]{2}{*}{ BM } & 210 & 6.67 & 0.22 & 6.69 & 0.16 & 6.99 & 0.19 & - \\
\hline & 365 & 6.02 & 0.22 & 6.46 & 0.16 & 6.55 & 0.19 & $1: 2,3^{*}$ \\
\hline \multirow[t]{2}{*}{ MLLT } & 210 & 50.67 & 2.35 & 52.80 & 1.71 & 58.05 & 2.08 & $1: 3^{* *}, 2: 3^{*}$ \\
\hline & 365 & 64.11 & 2.62 & 63.82 & 1.91 & 64.35 & 2.32 & - \\
\hline
\end{tabular}


2c-WW 365

\begin{tabular}{lcccccccc}
\hline \multirow{2}{*}{ Trait } & \multirow{2}{*}{ Age } & \multicolumn{2}{c}{$<28.4 \mathrm{~cm}, n=54$} & $28.4-31.7 \mathrm{~cm}, n=49$ & \multicolumn{2}{c}{$>31.7 \mathrm{~cm}, n=28$} & \multirow{2}{*}{$P$} \\
& & $\mu+\alpha$ & $\mathrm{SE}$ & $\mu+\alpha$ & $\mathrm{SE}$ & $\mu+\alpha$ & $\mathrm{SE}$ & \\
\hline BM & 365 & 6.35 & 0.15 & 6.39 & 0.18 & 6.96 & 0.24 & $1: 3^{* *}, 2: 3^{* *}$ \\
MLLT & 365 & 62.07 & 1.77 & 65.68 & 2.10 & 72.83 & 2.73 & $1: 3^{* * *}, 2: 3^{* *}$ \\
\hline
\end{tabular}

$\mu+\alpha$ least square mean, SE standard error of least square mean, $P$ statistical significances of differences between groups, ${ }^{*} P<0.05$, ${ }^{* *} P<0.01$, ${ }^{* * *} P<0.001$

Table 3 presents the relationships between BM at 120, 210 and 365 days of age and the MLLT area in the 1st LV. Significant differences of evaluated variables were found in relation to $\mathrm{BM}$. However, a direct trend was confirmed only at the evaluation of BM at 210 days of age in relationship to BM at 120 days of age, further at evaluation of the MLLT area at 210 and 365 days of age in relationship to BM at the same age, 210 and 365 days of age. It is possible to consider BM as an acceptable and practically usable trait of the MLLT area, and it can positively appreciate its inclusion in the system of linear description of the exterior of beef breeds. FIELD (2000) noted that it is possible to estimate the quality of carcass body by the use of prediction equotions based on muscling of animal. The present results confirm this fact, but under the condition of prediction for the same age, at which BM was evaluated. DVOŘÁKOVÁ et al. (2007) stated that the accuracy of estimation and the reliability of prediction decreased with the lengthening of the predicted period for estimation of the MLLT at higher age in relationship to live weight and WT of animal at a lower age.

Table 4 describes the effect of the MLLT in the 1st LV at 120 and 210 days of the animalss age on the MLLT at a higher age, meaning at 210 and 365 days of age. A direct dependence between a larger MLLT area at 120 and 210 days of age was detected, but without statistical significance. The same tendency was confirmed in relation to the MLLT at 210 and 365 days, with differences varying from $2.58 \mathrm{~cm}^{2}$ to $6.21 \mathrm{~cm}^{2}(P<0.05)$. The results do not indicate the possibility of objective prediction for the MLLT at a higher age according to its area at an age less than 210 days. This corresponded to the findings of DVOŘÁKOVÁ et al. (2007). Whereas PERKINS et al. (1992) and RÖSLER et al. (1996) presented the significant correlation coefficient of $r=0.60$ and 0.70 , respectively, for the relationship between the MLLT and musculus longissimus dorsi, respectively, at the same age measured via ultrasound and real area measured after slaughtering of the animal.

In conclusion a statistical significant effect of the sex, birth season, breed, and sire on the WT, WW and MLLT in the 1st LV and BM were determined. More significant trends as well as more significant differences, were found during evaluation of the observed characteristics at 210 and 365 days of age than at 120 days of age. Above all, from a practical point of view, the values of WT and WW as well, from 120 days of age and BM evaluated from 210 days of age can be considered for as acceptable traits for the selection of breeding animals concentrating on the MLLT area and these traits can be used for determination of selection standards oriented towards the muscling of animals. It can positively declare that evaluation of BM is a routine part of the linear description of beef breeds' exterior, as the level of BM from 210 days of age is significantly correlated to the MLLT. At the same time, according to the present results, it is possible to propose measurement of the WT as a more objective trait of body proportions and the MLLT of evaluated animals as early as from 120 days of age. 


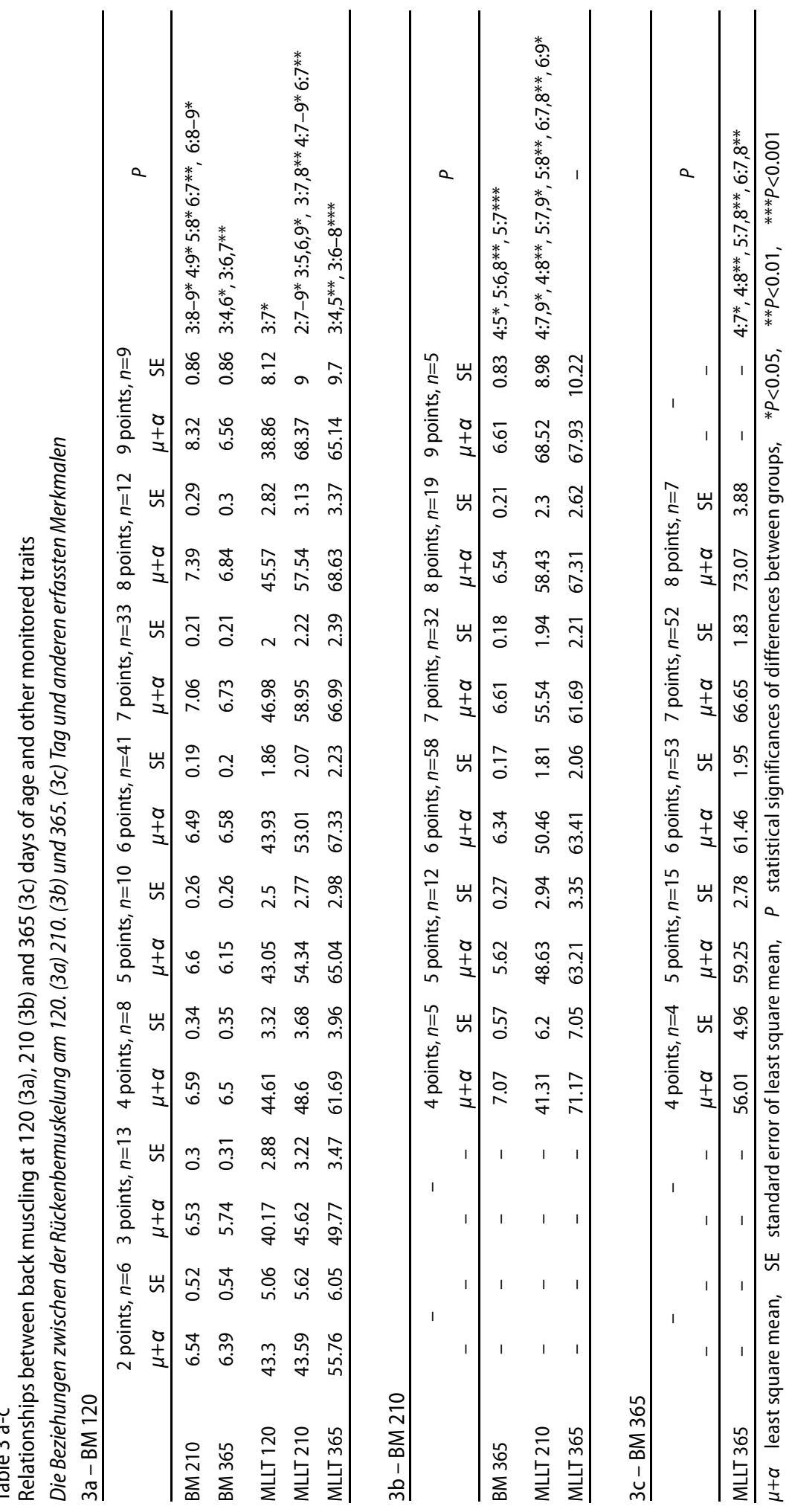


Table 4 a, b

Relationships between the MLLT area in the 1st lumbar vertebra at 120 (4a), 210 (4b) and 365 days of age and other monitored traits

Die Beziehungen zwischen der MLLT-Fläche am 1. Lendenwirbel am 120. (4a) 210. (4b) und 365. Tag und anderen erfassten Merkmalen

$4 \mathrm{a}-$ MLLT 120

\begin{tabular}{lcccccccc}
\hline \multirow{2}{*}{ Trait } & \multirow{2}{*}{ Age } & \multicolumn{2}{c}{$<40.1 \mathrm{~cm}^{2}, n=44$} & \multicolumn{2}{c}{$40.1-48.5 \mathrm{~cm}^{2}, n=50$} & \multicolumn{2}{c}{$>48.5 \mathrm{~cm}^{2}, n=37$} & \multirow{2}{*}{$P$} \\
& & $\mu+\alpha$ & $\mathrm{SE}$ & $\mu+\alpha$ & $\mathrm{SE}$ & $\mu+\alpha$ & $\mathrm{SE}$ & \\
\hline \multirow{2}{*}{ MLLT } & 210 & 52.26 & 1.86 & 53.79 & 1.88 & 55.97 & 2.09 & - \\
& 365 & 64.08 & 2.06 & 63.52 & 2.07 & 64.50 & 2.31 & - \\
\hline
\end{tabular}

$4 \mathrm{~b}-$ MLLT 210

\begin{tabular}{lcccccccc}
\hline \multirow{2}{*}{ Trait } & \multirow{2}{*}{ Age } & \multicolumn{2}{c}{$<50.3 \mathrm{~cm}^{2}, n=39$} & \multicolumn{2}{c}{$50.3-60.3 \mathrm{~cm}^{2}, n=55$} & \multicolumn{2}{c}{$>60.3 \mathrm{~cm}^{2}, n=37$} & $P$ \\
& & $\mu+\alpha$ & SE & $\mu+\alpha$ & SE & $\mu+\alpha$ & SE & \\
\hline MLLT & 365 & 60.82 & 2.21 & 64.45 & 1.86 & 67.03 & 2.25 & $1: 3^{*}$ \\
\hline
\end{tabular}

$\mu+\alpha$ least square mean, SE standard error of least square mean, $P$ statistical significances of differences between groups, ${ }^{*} P<0.05$, ${ }^{* *} P<0.01$, ${ }^{* * *} P<0.001$

\section{Acknowledgements}

This research was funded by the Ministry of Education, Youth, and Sports of the Czech Republic (Project No.MSM 6046070901) and by the Ministry of Agriculture of the Czech Republic (Project No.NAZV QF3020).

We thank Mrs. Lois Russell for her editorial help with this manuscript.

\section{References}

Alonso J, Bahamonde A, Villa A, Castaňón ÁR (2007) Morphological assessment of beef cattle according to carcass value. Liv Sci 107, 265-73

Bartoň L, Řehák D, Teslík V, Bureš D, Zahrádková R (2006) Effect of breed on growth performance and carcass composition of Aberdeen Angus Charolais Hereford and Simmental bulls. Czech J Anim Sci 51, 47-53

Bartoň L, Kudrna V, Bureš D, Zahrádková R, Teslík V (2007) Performance and carcass quality of Czech Fleckvieh Charolais and Charolais $\times$ Czech Fleckvieh bulls fed diets based on different types of silages. Czech J Anim Sci 52, 269-76

Bene S, Nagy B, Nagy L, Kiss B, Polgár Jp, Szabó F (2007) Comparison of body measurements of beef cows of different breeds. Arch Tierz 50, 363-373

Bergen R, Miller SP, Mandell IB, Robertson WM (2005) Use of live ultrasound weight and linear measurements to predict carcass composition of young beef bulls. Canadian J Anim Sci 85, 23-35

Brethour JR (2000) Using serial ultrasound measures to generate models of marbling and backfat thickness changes in feedlot cattle J Anim Sci 78, 2055-61

Bullock KD, Bertard JK, Benyshek LI, Williams SE, Lust DG (1991) Comparison of real-time ultrasound and other live measures to carcass measures as predictors of beef cow energy stress. J Anim Sci 69, 3908-16

Choat WT, Paterson JA, Rainey BM, King MC, Smith GC, Belk KE, Lipsey RJ (2006) The effects of cattle sex on carcass characteristics and longissimus muscle palatability. J Anim Sci 84, 1820-6

Coopman F, Van Zeveren A, Verhoeven G, De Smet S (2007) Parameters for the estimation of live weight and for the visual appraisal of the muscular conformation in the (double-muscled) Belgian Blue beef breed. Arch Tierz 50, 348-55

Drennan MJ, Mcgee M (2006) Relationship of visual and skeletal scores and scanner muscle measurements with carcass grades composition and value of steers. Book of Abstracts of the 57th EAAP meeting September 17-20, Antalya Turkey, 56 
Dvořáková J, Stádník L, Louda F, Ježková A (2007) The possibility and accuracy of MLLT area prediction during the rearing period of Blonde de Aquitaine cattle in the Czech Republic. Výzkum v chovu skotu - Cattle Research 49, 19-33

Engelhardt G, Branscheid W, Glodek P (1992) Estimating of the main tissue composition of bovine carcases by means of carcase traits. I. Behaviour of single traits. Arch Tierz 35, 561-9 [in German]

Field CM (2000) Use of live animal carcass ultrasound in stocker grazing in Mississippi. J Anim Sci 78 Suppl 1, 113

Hassen A, Wilson DE, Rouse GH (1999) Evaluation of carcass live and real-time ultrasound measures in feedlot cattle II Effects of different age end points on the accuracy of predicting the percentage of retail product retail product weight and hot carcass weight. J Anim Sci 77, 283-90

Hassen A, Wilson DE, Willham RL, Rouse GH, Trenkle AH (1998) Evaluation of ultrasound measurements of fat thickness and longissimus muscle area in feedlot cattle Assessment of accuracy and repeatability Canadian. J Anim Sci 78, 277-85

Herring WO, Miller DC, Bertrand JK, Benyshek LL (1994) Evaluation of machine technician and interpreter effects on ultrasonic measures of backfat and longissimus muscle area in beef cattle. J Anim Sci 72, 2216-26

Holló G, Ender K, Lóki K, Seregi J, Holló I, Nuernberg K (2008) Carcass characteristics and meat quality of Hungarian Simmental young bulls fed different forage to concentrate ratios with or without linseed supplementation. Arch Tierz 51, 517-30

Krejčová H, Mielenz N, Přibyl J, Schüler L (2007a) Estimation of genetic parameters for daily gains of bulls with Multi-Trait and Random Regression models. Arch Tierz 50, 37-46

KrejčovÁ H, Mielenz N, Přibyl J, Schüler L (2007b) Comparison of breeding values for daily gains of bulls estimated with Multi-Trait and Random Regression models. Arch Tier 50, 147-54

May SG, Mies WL, Edwards JW, Harris JJ, Morgan JB, Garrett RP, Williams FL, Wise JW, Cross HR, Savelu JW (2000) Using live estimates and ultrasound measurements to predict beef carcass mutability. J Anim Sci 78, 1255-61

Marle-Köster van E, Mosstert BE, Westhuizen van der J (2000) Body measurement as selection criteria for growth in South Africa Hereford cattle. Arch Tierz 43, 5-15

Nová V, Vaněk D, Kolářský F, Bukač V (2003) Growth ability and muscling evaluation with use the ultrasound in beef breeds of cattle in rearing station of sires. Výzkum v chovu skotu - Cattle Research 45, 17-24 [in Czech]

Perkins TL, Green RD, Hamlin KE (1992) Evaluation of Ultrasonic Estimates of Carcass Fat Thickness and Longissimus Muscle Area in Beef Cattle. J Anim Sci 70, 1002-10

Pfeiffer D, Leuthold G, Wärnke J, Kairies O (1985) Preliminary results of studies on carcass value recordings in live cattle by means of ultrasound. Arch Tierz 28, 111-20 [in German]

Polák P, Daňo J (2002) Contribution of ultrasound to objectification of slaughtered bulls encashment. Proc »Cattle in new millenium « September 4-5 SPU Nitra Slovak Republic, 126 [in Slovak]

Polák P, Sakowski T, Blanco Roa EN, Huba J, Krupa E, Tomka J, Peškovičová D, Oravcová $M$, Strapák $P$ (2007) Use of computer image analysis for in vivo estimates of the carcass quality of bulls. Czech J Anim Sci 52, 430-6

Přibyl J, Krejčová H, Přibylová J, Misztal I, Bohmanová J, Štípková M (2007) Trajectory of body weight of performance tested dual-purpose bulls. Czech J Anim Sci 52, 315-24

Přibyl J, Přibylová J, Krejčová H, Mielenz N (2008a) Comparison of different traits to evaluate the growth of bulls. Czech J Anim Sci 53, 273-83

Přibyl J, Krejčová H, Přibylová J, Misztal I, Tsuruta S, Mielenz N (2008b) Models for evaluation of growth of performance tested bulls. Czech J Anim Sci 53, 45-54

Rasch D, Mašata O (2006) Methods of variance component estimation. Czech J Anim Sci 51, 227-35

Rösler HJ, Lengerken von G, Wicke M, Scheeder MRL, Beisch B (1996) Investigations on the accuracy and the application of ultrasonic measurements for predicting carcass composition on live cattle. Arch Tierz 39, 401-13

SAS Institute (2001) SAS v 8.02 (TS2MO). SAS Institute Inc Cary NC

Steinhauser L, Beňovký R, Bystrický P (2000) Meat Production, Brno [in Czech]

Szabó F, Nagy L, Dákay I, Márton D, Török M, Bene SZ (2006) Effects of breed age of dam birth year birth season and sex on weaning weight of beef calves. Liv Sci 103, 181-5

Veselá Z, Přibyl J, Vostrý L, Šafus P, Štolc L, Šeba K (2006) The estimation of genetic parameters the exterier marks for flash breeds. Acta fytotechnica et zootechnica $9 \mathrm{SI}, 88-90$ [in Czech] 
Voříšková J, Frelich J, Říha J, Šubrt J (2002) Relationships between parameters of meat performance in Czech Pied bulls and their crossbreds with beef breeds. Czech J Anim Sci 47, 357-64

Vostrý L, Jakubec V, Schlote W, Bjelka M, Bezdíček J, Majzlík I (2008) Analysis of population and heterosis effects in crossbred cattle of Czech Fleckvieh and Beef Simmental parentage for growth traits. Arch Tierz 51, 207-15

Received 26 May 2008, accepted 22 February 2009.

Corresponding author:

Ing. LUDĚK STÁDNÍK, PhD

email: stadnik@af.czu.cz

Department of Animal Husbandry, Faculty of Agrobiology, Food and Natural Resources, Czech University of Life Sciences Prague, Kamýcká 129, 165 21, Prague 6 - Suchdol, Czech Republic 